\title{
Tranquillimonas alkanivorans gen. nov., sp. nov., an alkane-degrading bacterium isolated from Semarang Port in Indonesia
}

\author{
Correspondence \\ Yuki Kasai \\ yuki.kasai@mbio.jp
}

\author{
Theresia Umi Harwati, ${ }^{1} 2$ Yuki Kasai, ${ }^{1}$ Yumiko Kodama, ${ }^{1}$ \\ Dwi Susilaningsih $^{2}$ and Kazuya Watanabe ${ }^{1}$ \\ ${ }^{1}$ Marine Biotechnology Institute, 3-75-1 Heita, Kamaishi, Iwate 026-0001, Japan
${ }^{2}$ Research Centre for Biotechnology, Indonesia Institute of Sciences (LIPI), Cibinong 11691 ,
Indonesia
}

Strain $\mathrm{A} 34^{\top}$, an obligately halophilic, Gram-negative, non-motile, rod-shaped bacterium, was isolated from seawater obtained from Semarang Port in Indonesia. It possesses a pink pigment and degrades short-chain alkanes. It is positive for catalase and oxidase and reduces nitrate to nitrite. Analyses of $16 \mathrm{~S}$ rRNA gene sequences revealed a clear affiliation of this strain with the family 'Rhodobacteraceae' in the class Alphaproteobacteria, with its closest relatives being Salipiger mucosus $\mathrm{A}^{\top}$ ( $94.9 \%$ sequence similarity) and Palleronia marisminoris $\mathrm{B}^{\mathrm{T}} 3^{\top}$ (93.4\%). The DNA G $+C$ content was 69.1 mol\%. The major cellular fatty acids of strain $A 34^{\top}$ were $\mathrm{C}_{18: 1} \omega 7 c(56.2 \%), \mathrm{C}_{19: 0}$ cyclo $\omega 8 c(26.0 \%)$ and $\mathrm{C}_{16: 0}(9.1 \%)$, while the predominant respiratory lipoquinone was ubiquinone-10. Based on the physiological and phylogenetic data, it is proposed that strain $A 34^{\top}$ should be classified in a new genus and species, for which the name Tranquillimonas alkanivorans gen. nov., sp. nov. is proposed. The type strain of Tranquillimonas alkanivorans is strain $\mathrm{A}_{3} 4^{\top}\left(=\mathrm{JCM} 14836^{\top}=\mathrm{DSM} 19547^{\top}\right)$.
Contamination of the marine environment with petroleum hydrocarbons is of great public concern because of their toxicity to humans and marine organisms (Malins et al., 1985; Meador et al., 1995). Many studies have therefore been aimed at the isolation of marine hydrocarbondegrading bacteria (Kasai et al., 2002a, b; Ozaki et al., 2006); however, information regarding tropical hydrocarbon-degrading bacteria is relatively scarce (Chaillan et al., 2004; Zhuang et al., 2003; Zinjarde \& Pant, 2002). We have recently isolated 153 marine bacteria from seawater obtained from the Semarang Port in Indonesia and analysed their hydrocarbon-degrading abilities (Harwati et al., 2007). Among them, based on $16 \mathrm{~S}$ rRNA gene analyses, an alkane-degrading bacterium, strain $\mathrm{A} 34^{\mathrm{T}}$, was considered to represent a novel taxon (Harwati et al., 2007). Here, we investigate the taxonomic characteristics of strain $\mathrm{A} 34^{\mathrm{T}}$.

Cell morphology was examined by transmission electron microscopy (Beveridge et al., 1994), while motility was checked under a phase-contrast microscope. Gram staining and oxidase and catalase tests were performed using the procedures of Smibert \& Krieg (1994). Growth was tested at $30{ }^{\circ} \mathrm{C}$ in marine broth 2216 (MB) (Difco) unless

Abbreviation: PHA, poly- $\beta$-hydroxyalkanoate.

The GenBank/EMBL/DDBJ accession number for the $16 \mathrm{~S}$ rRNA gene sequence of strain $A 34^{\top}$ is $A B 302386$. otherwise stated. Salinity requirements were tested at $30{ }^{\circ} \mathrm{C}$ using modified MB (Sohn et al., 2004) supplemented with $0-20 \%(\mathrm{w} / \mathrm{v}) \mathrm{NaCl}$. The $\mathrm{pH}$ range and optimum were determined at $30{ }^{\circ} \mathrm{C}$ using marine 2216 agar (MA), the $\mathrm{pH}$ of which had been adjusted to $\mathrm{pH} 5.5-11$ using $\mathrm{HCl}$ and $\mathrm{KOH}$. Detection of poly- $\beta$-hydroxyalkanoate (PHA) was done using Sudan black (de Lima et al., 1999). Susceptibility to antibiotics was determined on MA plates in the presence of the following antibiotics at the concentrations given $\left(\mu \mathrm{g} \mathrm{ml}^{-1}\right)$ : ampicillin $(50,100,150$ and 200), chloramphenicol (20), gentamicin (50), kanamycin sulfate (20), nalidixic acid (20,50, 100 and 200), neomycin (50), streptomycin (20), tetracycline (10) and spectinomycin (7.5, 15 and 20). API ZYM, API 20NE (both from bioMérieux) and Microlog GN2 plates (Biolog) were used for physiological and biochemical characterization according to the manufacturers' instructions.

Cells of strain $\mathrm{A} 34^{\mathrm{T}}$ were Gram-negative, non-motile, straight rods $(1.7-2.8 \mu \mathrm{m}$ long and $0.2-0.5 \mu \mathrm{m}$ wide) that lacked flagella. The strain formed pink colonies on MA plates and was capable of growth on decane as a sole source of carbon and energy. It was positive in oxidase, catalase and nitrate reduction (nitrite was the final product) tests. Cells contained PHA. Growth of strain $\mathrm{A} 34^{\mathrm{T}}$ was observed between 10 and $50{ }^{\circ} \mathrm{C}$, with optimum growth at $43{ }^{\circ} \mathrm{C}$. Strain $\mathrm{A} 34^{\mathrm{T}}$ grew at $\mathrm{pH}$ 6.5-9.5, with optimum growth at 
$\mathrm{pH}$ 8.5. It showed an absolute requirement for $\mathrm{NaCl}$, as no growth was observed in medium without $\mathrm{NaCl}$. Strain $\mathrm{A} 34^{\mathrm{T}}$ grew at $1-13 \% \mathrm{NaCl}$, with optimum growth at $2 \%$. The physiological and biochemical characteristics of strain $\mathrm{A} 34^{\mathrm{T}}$ are given in the species description. Strain $\mathrm{A} 34^{\mathrm{T}}$ was susceptible to ampicillin, chloramphenicol, gentamicin, kanamycin, neomycin, spectinomycin, streptomycin and tetracycline, but resistant to nalidixic acid.

Cellular fatty acids and quinones were analysed by TechnoSuruga Laboratory Co., Ltd, using cells grown in $\mathrm{MB}$ for $24 \mathrm{~h}$. The fatty acids $(\geqslant 0.1 \%)$ of strain $\mathrm{A} 34^{\mathrm{T}}$ were $\mathrm{C}_{18: 1} \omega 7 c(56.23 \%), \mathrm{C}_{19: 0}$ cyclo $\omega 8 c(25.95 \%), \mathrm{C}_{16: 0}$ (9.05\%), $\mathrm{C}_{13: 0} 3-\mathrm{OH}(2.33 \%), \mathrm{C}_{18: 0}(1.58 \%), 11-$ methyl $\mathrm{C}_{18: 1} \omega 7 c(0.80 \%), \mathrm{C}_{16: 1} \omega 7 c$ and/or $\mathrm{C}_{15: 0}$ iso $2-\mathrm{OH}$ $(0.71 \%), \quad \mathrm{C}_{20: 2} \omega 6,9 c \quad(0.70 \%), \mathrm{C}_{17: 0} \quad(0.54 \%), \quad \mathrm{C}_{10: 0}$ $(0.51 \%), \mathrm{C}_{20: 1} \omega 7 c(0.50 \%)$ and $\mathrm{C}_{17: 0}$ cyclo $(0.40 \%)$ (Table 1 ). The fatty acid profile did not match any species profile available in the Sherlock Microbial Identification System database (MIDI, Inc.). The presence of $\mathrm{C}_{18: 1} \omega 7 c$ as the predominant fatty acid is a feature characteristic of taxa within the class Alphaproteobacteria. Nevertheless, the cyclo-substituted fatty acid $\mathrm{C}_{19: 0}$ cyclo $\omega 8 \mathrm{c}$ is not widely present in the family 'Rhodobacteraceae'. The only respiratory lipoquinone found in strain $\mathrm{A} 34^{\mathrm{T}}$ was ubiquinone10. The presence of ubiquinone-10 as the dominant respiratory lipoquinone is characteristic of members of the class Alphaproteobacteria.

The 16S rRNA gene sequence of strain $\mathrm{A} 34^{\mathrm{T}}$ (1364 bp) was determined previously (Harwati et al., 2007). A sequence similarity search was conducted using the GenBank and RDP (Maidak et al., 1999) databases. Phylogenetic analysis was performed using CLUSTAL_X (version 1.83) (Thompson et al., 1997), and a phylogenetic tree was constructed using the neighbour-joining plot program in MEGA version 3.0 (Kumar et al., 2004). Phylogenetic analysis of the 16S rRNA

Table 1. Cellular fatty acid compositions of strain $A 34^{\top}$ and related members of the family 'Rhodobacteraceae'

Strains: 1, strain $\mathrm{A} 34^{\mathrm{T}} ; 2$, Salipiger mucosus $\mathrm{A} 3^{\mathrm{T}}$ (data from MartínezCánovas et al., 2004); 3, Palleronia marisminoris $\mathrm{B}_{3}{ }^{\mathrm{T}}$ (Martínez- $^{-}$ Checa et al., 2005). Values are percentages of total fatty acids; fatty acids that accounted for less than $1 \%$ of the total in all strains are not shown. - , Not detected/not reported.

\begin{tabular}{|lccc|}
\hline Fatty acid & $\mathbf{1}$ & $\mathbf{2}$ & $\mathbf{3}$ \\
\hline $\mathrm{C}_{16: 0}$ & 9.1 & 12.4 & 4.3 \\
$\mathrm{C}_{18: 0}$ & 1.6 & 2.0 & 3.4 \\
$\mathrm{C}_{16: 1} \omega 7 c$ & - & 1.3 & - \\
$\mathrm{C}_{18: 1} \omega 7 c$ & 56.2 & 78.0 & 68.9 \\
$\mathrm{C}_{10: 0} 3-\mathrm{OH}$ & - & - & 5.0 \\
$\mathrm{C}_{12: 0} 3-\mathrm{OH}$ & 2.3 & - & - \\
$\mathrm{C}_{12: 1} 3-\mathrm{OH}$ & - & 2.3 & - \\
$11-$ Methyl $\mathrm{C}_{18: 1} \omega 7 c$ & - & 1.9 & - \\
$\mathrm{C}_{19: 0}$ cyclo $\omega 8 c$ & 26.0 & 12.8 & 2.3 \\
\hline
\end{tabular}

gene sequence showed that strain $\mathrm{A} 34^{\mathrm{T}}$ was affiliated with the 'Rhodobacteraceae' (Fig. 1). The closest relative of strain $\mathrm{A} 34^{\mathrm{T}}$ was Salipiger mucosus $\mathrm{A} 3^{\mathrm{T}}$ (94.9\% $16 \mathrm{~S}$ rRNA gene sequence identity), while Palleronia marisminoris $\mathrm{B}^{3} 3^{\mathrm{T}}$ $(93.4 \%)$ was the second closest relative. The G $+\mathrm{C}$ content of strain $\mathrm{A} 34^{\mathrm{T}}$ as determined by the method of KatayamaFujimura et al. (1984) was $69.1 \mathrm{~mol} \%$.

Table 2 shows several phenotypic traits of strain $\mathrm{A} 34^{\mathrm{T}}$ that can differentiate it from phylogenetically related bacteria in the 'Rhodobacteraceae'. Based on phylogeny, fatty acid profile, $\mathrm{G}+\mathrm{C}$ content and phenotypic characteristics (e.g. nitrate reduction), we conclude that strain $\mathrm{A} 34^{\mathrm{T}}$ should be recognized as a representative of a novel genus and species, for which the name Tranquillimonas alkanivorans gen. nov., sp. nov. is proposed.

\section{Description of Tranquillimonas gen. nov.}

Tranquillimonas (Tran.quil'li.mo'nas. L. adj. tranquillus quiet, calm, still; L. fem. n. monas a unit, monad; N.L. fem. n. Tranquillimonas a still monad).

Cells are Gram-negative, non-motile rods (1.7-2.8 $\mu \mathrm{m}$ long and $0.2-0.5 \mu \mathrm{m}$ wide). Obligately halophilic: $\mathrm{Na}^{+}$ions are required for growth. Form pink colonies when grown on MA plates. Tests for oxidase and catalase are positive. Contain PHA. The major ubiquinone is Q-10. Dominant fatty acids are $\mathrm{C}_{18: 1} \omega \omega c, \mathrm{C}_{19: 0}$ cyclo $\omega 8 c$ and $\mathrm{C}_{16: 0}$. The type species is Tranquillimonas alkanivorans.

\section{Description of Tranquillimonas alkanivorans sp. nov.}

Tranquillimonas alkanivorans (al.ka' ni.vo' rans. N.L. neut. n. alkanum alkane; L. part. adj. vorans devouring; N.L. part. adj. alkanivorans alkane-degrading).

The description is identical to that of the genus, with the following additions. Growth occurs at $10-50{ }^{\circ} \mathrm{C}$ (optimum $43{ }^{\circ} \mathrm{C}$ ), pH 6.5-9.5 (optimum $\left.\mathrm{pH} 8.5\right)$ and $1-13 \%(\mathrm{w} / \mathrm{v})$ $\mathrm{NaCl}$ (optimum 2\%). Susceptible to ( $\mu \mathrm{g}$ per disc) ampicillin (50), chloramphenicol (20), gentamicin (50), kanamycin (20), neomycin (50), spectinomycin (7.5), streptomycin (20) and tetracycline (10), but resistant to nalidixic acid (200). Tests for nitrate reduction, $\beta$ glucosidase, protease, alkaline phosphatase, esterase (C4), esterase lipase (C8), leucine arylamidase, acid phosphatase, naphthol-AS-BI-phosphohydrolase, $\alpha$-glucosidase, $\beta$-glucosidase and ONPG are positive. Tests for indole production, glucose fermentation, urease, arginase, lipase (C14), valine arylamidase, cystine arylamidase, trypsin, $\alpha$ chymotrypsin, $\alpha$-galactosidase, $\beta$-galactosidase, $\beta$-glucuronidase, $N$-acetyl- $\beta$-glucosaminidase, $\alpha$-mannosidase and $\alpha$ fucosidase are negative. The following compounds are utilized as carbon sources in the Biolog GN2 plate: Tweens 40 and 80, L-arabinose, D-fructose, L-fructose, D-galactose, gentiobiose, $\alpha$-D-glucose, myo-inositol, $\alpha$-D-lactose, lactulose, maltose, D-mannitol, methyl $\beta$-D-glucose, D-psicose, raffinose, L-rhamnose, D-sorbitol, sucrose, trehalose, 


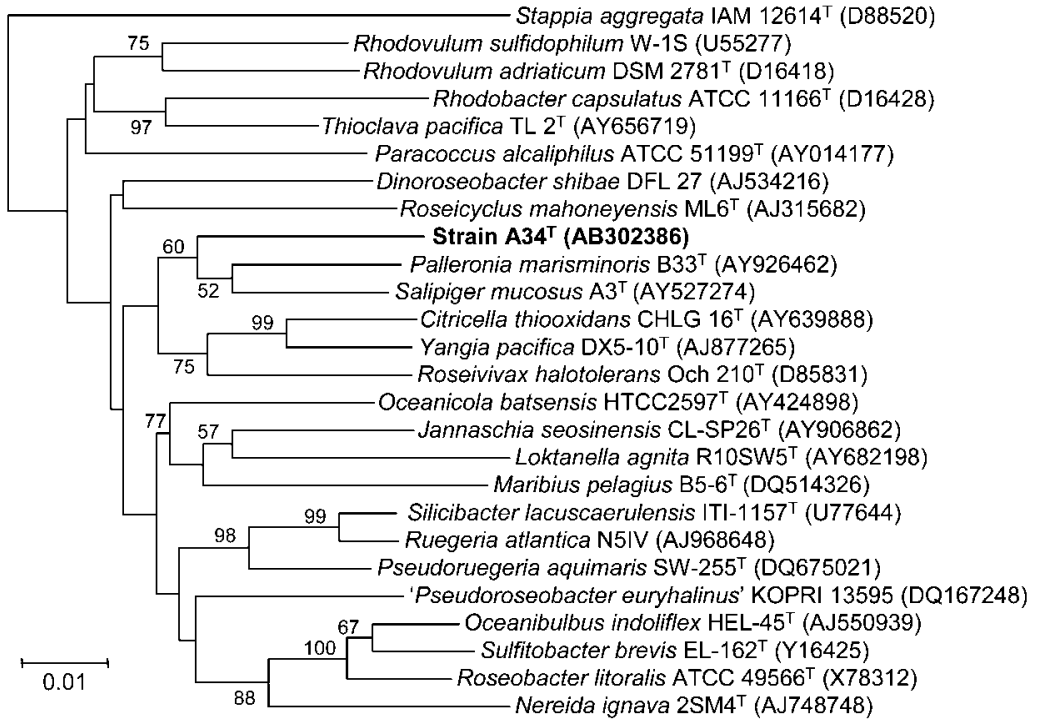

Fig. 1. Phylogenetic relationships between strain $\mathrm{A} 34^{\mathrm{T}}$ and members of other genera in the family 'Rhodobacteraceae' based on $16 \mathrm{~S}$ rRNA gene sequences. The tree was constructed using the neighbour-joining algorithm. Only bootstrap values above 50 (from 100 replications) are shown. Bar, $1 \%$ estimated sequence divergence. turanose, xylitol, pyruvic acid, citric acid, formic acid, Dgalactonic acid lactone, D-galacturonic acid, D-gluconic acid, D-glucosaminic acid, D-glucuronic acid, $\alpha$-hydroxybutyric acid, $\beta$-hydroxybutyric acid, $\alpha$-ketoglutaric acid, Dand L-lactic acid, succinamic acid, glucuronamide, aspartic acid, D- and L-alanine, L-alanyl glycine, L-asparagine, Laspartic acid, L-glutamic acid, glycyl L-aspartic acid, hydroxy-L-proline, L-leucine, L-ornithine, L-phenylalanine,
L-proline, L-pyroglutamic acid, $\mathrm{D}$ - and L-serine and Lthreonine. Degrades alkanes $\left(\mathrm{C}_{10-13}\right)$. Dominant fatty acids (\%) are $\mathrm{C}_{18: 1} \omega 7 c(56.2), \mathrm{C}_{19: 0}$ cyclo $\omega 8 c(26.0), \mathrm{C}_{16: 0}$ (9.1) and $\mathrm{C}_{13: 0} 3-\mathrm{OH}(2.3)$. The DNA G $+\mathrm{C}$ content of the type strain is $69.1 \mathrm{~mol} \%$.

The type strain, A34 ${ }^{\mathrm{T}}$ (=JCM $14836^{\mathrm{T}}=\mathrm{DSM} 19547^{\mathrm{T}}$ ), was isolated from seawater in Semarang Port, Indonesia.

Table 2. Characteristics that distinguish strain $A 34^{\top}$ from related members of the family 'Rhodobacteraceae'

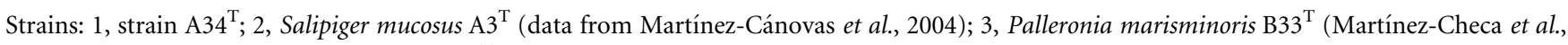
2005); 4, Roseivivax halotolerans JCM $10271^{\mathrm{T}}$ (Suzuki et al., 1999; Nishimura et al., 1994). +, Positive; -, negative; ND, no data available.

\begin{tabular}{|c|c|c|c|c|}
\hline Characteristic & 1 & 2 & 3 & 4 \\
\hline Source & Seawater & Hypersaline soil & Hypersaline soil & $\begin{array}{c}\text { Cyanobacterial mat in a } \\
\text { saline lake }\end{array}$ \\
\hline Pigmentation & Pink & - & Pink & Pink \\
\hline Flagella & - & - & - & Single, subpolar \\
\hline PHA & + & + & + & ND \\
\hline Oxidase & + & + & - & + \\
\hline Temperature range $\left({ }^{\circ} \mathrm{C}\right)$ & $10-50$ & $20-40$ & $20-37$ & $27-30^{\star}$ \\
\hline \multicolumn{5}{|c|}{$\mathrm{NaCl}$ concentration for growth $(\% \mathrm{w} / \mathrm{v})$} \\
\hline Range & $1-13$ & $0.5-20$ & $0.5-15$ & $0.5-20$ \\
\hline Optimum & 2 & $9-10$ & 5 & ND \\
\hline Nitrate to nitrite & + & - & - & - \\
\hline Acid from glucose & - & - & - & + \\
\hline Indole & - & - & - & + \\
\hline ONPG & + & - & + & + \\
\hline Urease & - & + & - & + \\
\hline Phosphatase & + & + & + & - \\
\hline DNA G $+C$ content $(\mathrm{mol} \%)$ & 69.1 & 64.5 & 64.2 & 59.7 \\
\hline
\end{tabular}

${ }^{\star}$ Only the optimum temperature has been published. 


\section{Acknowledgements}

We are grateful to Professor Dr H. G. Trüper for his help with the genus and species names. We thank Hiromi Awabuchi and Midori Satoh for their technical assistance. This work was supported by the Japan International Cooperation Agency (JICA) and the Indonesian Institute of Sciences (LIPI).

\section{References}

Beveridge, T. J., Popkin, T. J. \& Cole, R. M. (1994). Electron microscopy. In Methods for General and Molecular Bacteriology, pp. 42-71. Edited by P. Gerhardt, R. G. E. Murray, W. A. Wood \& N. R. Krieg. Washington, DC: American Society for Microbiology.

Chaillan, F., Le Fleche, A., Bury, E., Phantavong, Y. H., Grimont, P., Saliot, A. \& Oudot, J. (2004). Identification and biodegradation potential of tropical aerobic hydrocarbon-degrading microorganisms. Res Microbiol 155, 587-595.

de Lima, T. C. S., Grisi, B. M. \& Bonato, M. C. M. (1999). Bacteria isolated from a sugarcane agroecosystem: their potential production of polyhydroxyalcanoates and resistance to antibiotics. Rev Microbiol 30, 214-224.

Harwati, T. U., Kasai, Y., Kodama, Y., Susilaningsih, D. \& Watanabe, K. (2007). Characterization of diverse hydrocarbon-degrading bacteria isolated from Indonesian seawater. Microbes Environ 22, 412-415.

Kasai, Y., Kishira, H. \& Harayama, S. (2002a). Bacteria belonging to the genus Cycloclasticus play a primary role in the degradation of aromatic hydrocarbons released in a marine environment. Appl Environ Microbiol 68, 5625-5633.

Kasai, Y., Kishira, H., Sasaki, T., Syutsubo, K., Watanabe, K. \& Harayama, S. (2002b). Predominant growth of Alkanivorax strains in oil-contaminated nutrient supplemented seawater. Environ Microbiol 4, 141-147.

Katayama-Fujimura, Y., Komatsu, Y., Kuraishi, H. \& Kaneko, T. (1984). Estimation of DNA base composition by high performance liquid chromatography of its nuclease P1 hydrolysate. Agric Biol Chem 48, 3169-3172.

Kumar, S., Tamura, K. \& Nei, M. (2004). MEGA3: integrated software for molecular evolutionary genetics analysis and sequence alignment. Brief Bioinform 5, 150-163.

Maidak, B. L., Cole, J. R., Parker, C. T., Jr, Garrity, G. M., Larsen, N., Li, B., Lilburn, T. G., McCaughey, M. J., Olsen, G. J. \& other authors (1999). A new version of the RDP (Ribosomal Database Project). Nucleic Acids Res 27, 171-173.

Malins, D. C., Krahn, M. M., Brown, D. W., Rhodes, L. D., Myers, M. S., McCain, B. B. \& Chan, S. L. (1985). Toxic chemicals in marine sediment and biota from Mukilteo, Washington: relationships with hepatic neoplasms and other hepatic lesions in English sole (Parophrys vetulus). J Natl Cancer Inst 74, 487-494.

Martínez-Cánovas, M. J., Quesada, E., Martínez-Checa, F., del Moral, A. \& Béjar, V. (2004). Salipiger mucescens gen. nov., sp. nov., a moderately halophilic, exopolysaccharide-producing bacterium isolated from hypersaline soil, belonging to the $\alpha$ Proteobacteria. Int J Syst Evol Microbiol 54, 1735-1740.

Martínez-Checa, F., Quesada, E., Martínez-Cánovas, M. J., Llamas, I. \& Béjar, V. (2005). Palleronia marisminoris gen. nov., sp. nov., a moderately halophilic, exopolysaccharide-producing bacterium belonging to the 'Alphaproteobacteria', isolated from a saline soil. Int J Syst Evol Microbiol 55, 2525-2530.

Meador, J. P., Stein, J. E., Reichert, W. L. \& Varanasi, U. (1995). Bioaccumulation of polycyclic aromatic hydrocarbons by marine organisms. Rev Environ Contam Toxicol 143, 79-165.

Nishimura, Y., Muroga, Y., Saito, S., Shiba, T., Takamiya, K. \& Shioi, $Y$ Y. (1994). DNA relatedness and chemotaxonomic features of aerobic bacteriochlorophyll-containing bacteria isolated from coasts of Australia. J Gen Appl Microbiol 40, 287-296.

Ozaki, S., Kishimoto, N. \& Fujita, T. (2006). Isolation and phylogenetic characterization of microbial consortia able to degrade aromatic hydrocarbons at high rates. Microbes Environ 21, 44-52.

Smibert, R. M. \& Krieg, N. R. (1994). Phenotypic characterization. In Methods for General and Molecular Bacteriology, pp. 607-655. Edited by P. Gerhardt, R. G. E. Murray, W. A. Wood \& N. R. Krieg. Washington, DC: American Society for Microbiology.

Sohn, J. H., Kwon, K. K., Kang, J.-H., Jung, H.-B. \& Kim, S.-J. (2004). Novosphingobium pentaromativorans sp. nov., a high-molecular-mass polycyclic aromatic hydrocarbon-degrading bacterium isolated from estuarine sediment. Int J Syst Evol Microbiol 54, 1483-1487.

Suzuki, T., Muroga, Y., Takahama, M. \& Nishimura, Y. (1999). Roseivivax halodurans gen. nov., sp. nov., and Roseivivax halotolerans sp. nov., aerobic bacteriochlorophyll-containing bacteria isolated from a saline lake. Int J Syst Bacteriol 49, 629-634.

Thompson, J. D., Gibson, T. J., Plewniak, K., Jeanmougin, F. \& Higgins, D. G. (1997). The CLUSTAL_X windows interface: flexible strategies for multiple sequence alignment aided by quality analysis tools. Nucleic Acids Res 25, 4876-4882.

Zhuang, W.-Q., Tay, J.-H., Maszenan, A. M. \& Tay, S. T.-L. (2003). Isolation of naphthalene-degrading bacteria from tropical marine sediments. Water Sci Technol 47 1, 303-308.

Zinjarde, S. S. \& Pant, A. A. (2002). Hydrocarbon degraders from tropical marine environments. Mar Pollut Bull 44, 118-121. 